\title{
Performance of Physical Education Teachers in State Universities in Samar Island: Basis for Ape Development Plan
}

\author{
Mary Lynn Espiña-Verano \\ Doctor of Philosophy In Educational Management, University of Eastern Philippines, University Town, Northern Samar
}

\begin{abstract}
This study was conducted to determine the performance of Physical Education teachers in state universities in Samar Island as basis for a PE development plan. Specifically, it aimed to identify the faculty's socio-demographic profile as to faculty and student factors and to identify the problems encountered by the faculty and their needs in their teaching performance, in terms of personal, student, instructional, and administrative factors. In addition, this ascertained if the faculty's socio-demographic profile correlated with their teaching performance and the problems they encountered and their needs in teaching performance. And this determined the significant difference between the evaluations of the four (4) state universities on the performance of the faculty. The study utilized descriptive-correlational research design. Covering four (4) state universities in Samar Island and faculty handling basic PE course, supervisors, and students participated in the study. Complete enumeration was employed for the faculty and supervisors while random sampling technique was used for the 2,156 students. A survey questionnaire was used as the primary instrument to gather data. The study used frequency counts, percentages, ranking, and weighted mean, $t$-test for independent samples and multiple regression analysis as statistical tools. Most of the faculty-respondents belonged to 30 to 59 years old, female, married, earned appropriate post-graduate studies, earned a monthly salary of $P$ 35,000 and below, have been teaching for 1 to 15 years, attended 1 to 10 relevant seminars/trainings related to PE teaching, received 1 to 10 awards/incentives related to teaching PE, had a class size of 50 and below, had "highly favorable" teaching strategies, and "favorable" attitude towards teaching. Most of the student-respondents had access to books, received an average grade of 1.50 during the first semester, had "very good" study habits, and had a result of 51 to 75 in their school ability test. The faculty had a "very satisfactory" teaching performance, in terms of commitment, knowledge of subject matter, teaching for independent learning, management of student learning, course syllabus, methodology, performance, critic factor, instruction as to teacher, students, and learning environment, and other qualities. The faculty, the students, and the supervisors assessed that the faculty moderately encountered problems in terms of instructional, personal, administrative, and student factors. Moreover, the faculty, the students, and the supervisors perceived that the faculty was in "much needed" in their teaching performance as to personal, student, instructional, and administrative factors. On the test of relationship, it showed that all socio-demographic profile variables were found to be not significantly related to the teaching performance of faculty handling basic PE course. It also revealed that among the socio-demographic profile variables, only study habits affected the problems encountered by the faculty while other variables found to be not significantly correlated with the problems and needs of the faculty in their teaching performance. On the test of difference, there was no significant difference between the evaluation of the students in four (4) universities in Samar Island on the teaching performance of the faculty handling basic PE course. Based on the findings of this study, a PE Development Plan was formulated to further increase or improve the quality, desirability, attractiveness or effectiveness of the teaching performance of faculty handling basic PE course in state universities in Samar Island.
\end{abstract}

\section{Introduction}

The development of any country depends largely on the quality of education. An institution of learning should be manned by competent faculty. Without good teachers, students' academic development and better performance is not possible.

Accordingly, quality education may be attributed to the quality of teachers and the quality of teachers is a function of the quality of training they have. This is because in education, teachers play the biggest and the heaviest role in developing students to the fullest so they can contribute to a fully developed and progressive country as well.

The teacher may have the content or knowledge but he or she must have the methodology as well to effectively and efficiently harbor. In the teaching-learning situation, the students get something. Knowing and competent, the mentor must be caring, concerned to sustain the performance. In such manner the student is developed morally, physically, and intellectually to attain the good life.
Each teacher is different in character, intelligence, and ability. However, the target of every teacher is to be the best in achievement and performance. To be an ideal, competent and progressive teacher, s/he must possess personal and professional qualities of an effective teacher. Personal and professional qualities have a definite relationship to teaching competence which includes mastery of the subject field one teaches, understanding of the learner, understanding of teaching principles and skills in the use of techniques for their implementation, general understanding of other branches of knowledge, and understanding and appreciation of the teaching profession. Ramos (2001) believes that personal qualities are so interrelated with professional qualities that it is quite hard to isolate them but they add up to making the teacher effective.

Physical education teachers are responsible for promoting a healthy and positive environment for learning. A healthy positive environment can be created and maintained especially if a physical education teacher provides constructive and positive feedback. In addition, if a physical education teacher is prepared, provides well-organized activities, and establishes clear expectations, students will usually respond to the environment in a positive manner.

Volume 6 Issue 12, December 2017 


\section{International Journal of Science and Research (IJSR) \\ ISSN (Online): 2319-7064}

Index Copernicus Value (2016): 79.57 | Impact Factor (2015): 6.391

Physical education provides students the opportunity to enhance their physical, social, emotional, and cognitive development. This usually occurs during team sports, project adventure activities, problem-solving and physical fitness activities (Martin, et al., 2009).

Amid the changing environment, the Physical Education Curriculum (PEC) encourages and motivates students to adopt and pursue a healthy and active lifestyle through education and involvement in sports and other variety of physical and recreational activities. It also develops and strengthens the character of the students by engaging them in athletic and friendly competitions and activities that promote Philippine culture.

Furthermore, Hardman (2005) noted in his article that there was a decline or marginalization of the subject of Physical Education in schools, such as deficiencies were apparent in curriculum, time allocation, subject status, materials, human and financial resources, gender and disability issues, quality and program delivery, and teaching performance. Leonard A. de Vries as cited by Miguel (2013) believes that $60 \%$ of the physical education and sports programs in the Philippine schools suffer from low resources and deprived conditions because of, among others, important decisions are often made by government officials with no academic or professional qualifications in the discipline; and physical education and sports are commonly considered as "play" rather than subjects that develop the "thinking" capacity.

As observed by the researcher, the teaching performance of faculty handling basic PE course in the University of Eastern Philippines, based on the evaluation of the students, are not yet enhanced due to lack of trainings and seminars and that their academic/professional preparation are not enough to further improve the quality of teaching, likewise the quality of learning that should be learned by the students.

With this, Peterson (2005) calls for a new direction in teacher evaluation especially those handling basic PE course that will bring better results more allied to the goals of comprehensive professional development and the goals of education reform.

Studies conducted here and abroad on the teaching performance of PE faculty showed that their level of performance was very satisfactory as perceived by the students and by the supervisors. However, during the preliminary assessment conducted by the researcher, it has been observed that the teaching performance of the PE faculty in the four (4) state universities in Samar Island should still be enhanced despite very good results of the students' evaluation. This confirms with the study conducted by Miguel (2013) on the PE programs of higher education institutions (HEIs), which revealed that the PE curricular programs for both the general education and the degreegranting and teaching competencies of teachers were generally satisfactory but yet do not meet the minimum standards required by the CHED and ICHPER.SD. The other two program components, i.e. teacher characteristics and qualifications, and PE facilities and equipment were rated poor which signified that the HEIs failed to meet the minimum requirements set by the aforementioned bodies and by local and foreign PE specialists.

Hence, it is along these insights that gave a plausible reason for the researcher's preference to conduct a study on the performance of Physical Education teachers in state universities in Samar Island as basis in designing and proposing a PE development plan that will enhance and improve the teaching performance for PE instruction.

\section{Objectives of the Study}

This study was conducted to determine the performance of Physical Education teachers in state universities in Samar Island, as basis for a PE development plan.

Specifically, it aimed to:

1. identify the socio-demographic profile, in terms of:

1.1 faculty factors

1.1.1 age

1.1.2 sex

1.1.3 civil status

1.1.4 highest educational attainment/degree earned

1.1.5 monthly salary

1.1.6 length of teaching Physical Education

1.1.7 seminars/trainings attended related to PE teaching

1.1.8 incentives and awards

1.1.9 class size

1.1.10 teaching strategies

1.1.11 attitude towards teaching

1.2 student factors

1.2.1 personal learning resources

1.2.2 grade point average in first semester

1.2.3 study habits

1.2.4 school ability test

2. find out the performance of PE faculty as assessed and evaluated by their students, in terms of:

2.1 commitment

2.2 knowledge of subject matter

2.3 teaching for independent learning

2.4 management of student learning

2.5 course syllabus

2.6 methodology

2.7 performance

2.8 critic factor

2.9 instruction-teacher

2.10 instruction-students

2.11 instruction-learning environment

2.12 other qualities

3. identify possible problems that affects the teaching performance of the faculty, in terms of:

3.1 personal factor

3.2 student factor

3.3 instructional factor

3.4 administrative factor

4. determine the needs of the faculty in their teaching performance, in terms of:

4.1 personal factor

4.2 student factor

Volume 6 Issue 12, December 2017 


\section{International Journal of Science and Research (IJSR) \\ ISSN (Online): 2319-7064}

Index Copernicus Value (2016): 79.57 | Impact Factor (2015): 6.391

\section{3 instructional factor \\ 4.4 administrative factor}

5. find out if there is a significant relationship between the faculty's socio-demographic profile and their teaching performance;

6. ascertain if there is a significant relationship between the faculty's socio-demographic profile and the problems they encountered and their needs in teaching performance;

7. ascertain if there is a significant difference between the assessment and evaluation of the four (4) state universities on the performance of PE faculty; and

8. design a Physical Education development plan based on the findings of the study.

Shulman (2012) stated about the importance of any research on teaching: "teaching is and has always been at the center of all education and educational reform, thus, any research that focuses on teaching is significant, especially if it provides an empirical base that can guide policy actions concerning teachers".

In particular, this study is beneficial to the following:

Physical Education Faculty. The results of this study will help the faculty handling the PE basic course to devise innovative ways and means to improve their teaching methodologies and strategies suited to the learners' needs and capabilities, thus, prepare their students to take their places in the fast advancing world.

Physical Education Department. The results of this study would serve as feedback to the department as regards the strengths and weaknesses of PE instruction, which could be the basis for instituting in-service training activities like workshops and seminars directed to improve faculty's competences in Physical Education teaching.

Administrators. The findings of this research will help administrators implement appropriate means to ensure effective instruction, thus, improving the performance level of the students in various examinations and assess the faculty's teaching ability especially on the weak areas and further look into the possible solutions of being so.

Curriculum Planners. This study may serve as a guide in formulating and planning a curriculum that is highly attuned to the needs and demands of the learners facing the breakthroughs in technology and to lessen the deterioration of the student's study habits and competencies in various subjects, which are very much needed in the global market.

Teacher Education Institutions (TEIs). The findings of this study will serve as reference for TEIs concerning the instructors' teaching performance. It will be a challenge to these institutions to produce competent graduates of Teacher Education courses so that quality teaching and learning will be achieved, thus, enabling their future learners to perform very well in these subjects.
Students. The results of the study will benefit the students in by assessing the teaching performance of their PE faculty as it may reflect to their class standing. Moreover, this will be a way of reflecting on their own capabilities and which is turn may enhance positive attitude towards their studies that will lead to a better academic performance.

Future Researchers. The results of this study will benefit researchers who may desire to conduct a more intensive study on the relationship of faculty's performance and students' performance. Moreover, this particular research work will be a good source or reference material to the researchers in conceptualizing further studies on related topic or any study parallel to topics included here.

Scope and Limitation of the Study

This study aimed at determining the performance of Physical Education teachers in state universities in Samar Island.

The findings of the study were the basis in making a PE development plan to further increase or improve the quality and effectiveness of the Physical Education instruction.

This study was conducted in the four (4) state universities in Samar Island, i.e. Eastern Samar State University (Borongan City), Northwest Samar State University (Calbayog City), Samar State University (Catbalogan City), and University of Eastern Philippines (Catarman).

The faculty handling basic PE course were chosen as the respondents of the study. Moreover, the supervisors of the faculty and the students enrolled during the second semester, school year 2015-2016 were also included as the respondents.

This study was limited to the regular, permanent, or special lecturer faculty handling the PE subjects. Moreover, the problems encountered and needs of the faculty members few years back were also considered as limitations since these may not coincide with the present results/statements during the interviews. Furthermore, the students' assessment on their study habits reflected in general and not solely on the PE subjects.

The following theories provided strong bases to support the study.

The core theoretical basis of the study was the Waldman's Theory of Performance. The theory of Waldman (2004:510 530) has two different views - as result/outputs and as behaviors. Typically, behavior is regarded as one of the causes of output, with output being one of the means by which the effectiveness of performance may be judged. In other words, judgments are made about the effectiveness of employees with reference to what they accomplish the results they achieve, the output they produce.

Corollary to this, the Theory of Performance of Kukla explains that a person who perceives him/herself as an individual with positive outlook becomes successful in doing the task. On the other hand, when a person is highly reluctant in approaching an untried task, s/he is likely to treat the task as maximally difficult. If s/he succeeds, s/he 


\section{International Journal of Science and Research (IJSR) \\ ISSN (Online): 2319-7064}

Index Copernicus Value (2016): 79.57 | Impact Factor (2015): 6.391

will be inclined to perceive the task as less difficult. Success will continue to alter the perception on the level of difficulty of the task (Kukla, 2003).

In addition, Kontz's Work Theory says that work is emphasized as efforts directed to the accomplishment of some objectives. The theory stated that work as certainly accomplished outside organized enterprise not only as requirements for making a living but also an activity with no economic end in view, to viability. It is necessary to establish rules concerning attendance, working hours, place of work, working behaviors and what comprises the job itself.

Inevitably, the employees feel at loss of freedom but then still work in an organized enterprise. One reason expounded by the theory is that, this is one best opportunity to make a living. The need for income to purchase scarce and therefore costly goods and services require men to work. Taking stock of existing knowledge and skilled men will choose to secure income in which they will achieve their best input-output ratio (Kontz, 2003).

The Theory on the Influence of Basic Psychological Needs states that just as the individual has basic physical and organic needs which must be met in order that s/he may live, so are psychological needs which must be satisfied properly in order that the mind and the emotions may function adequately. Need implies something which is required for the individual to attain an end or objective commensurate with his/her nature, origin, and destiny. It involves psychological satisfaction, which can be attained largely through contacts with other people. Its significance rests on the fact that when fulfilled, it becomes source of satisfaction but when not satisfied, it becomes source of increased tension and conflict or frustration and are so manifest behavior (Kelly, 2015:464-465).

The need for self-esteem, for instance is sometimes designated as a sense of inner security. It involves a feeling of adequacy, of personal worth, of wholesome self-regard and self-respect, including awareness and a value of the dignity and uniqueness of the self as a human being. The need for self-reliance and self-confidence is often designated as the need to be independent. The satisfaction of these psychological needs provides the individual with feelings of worth and confidence, which help him to become adjusted (Kelly, 2015:464-465).

Another anchorage on this study is the Performance Management Theory of Action, which emphasizes the importance of teachers' educational background (SAT scores, class ranking in college, etc.) and performance characteristics (value-added contributions to student achievement, based on standardized test scores and compensation, and evaluation histories) to describe teacher effectiveness. Furthermore, the performance management perspective tends to treat effective teaching as an individual endeavor and thus seeks solutions focused on enhancing the identification and distribution of effective teachers in highminority, high-poverty schools (Wiske, 2008).

With this lens, the social, racial, cultural, cognitive, and linguistic histories and characteristics of students, practitioners, and communities are secondary, if not tertiary, considerations to understanding variations in teacher effectiveness. The reasoning of the performance management theory of actions states that if compensation and evaluation are tied to student achievement data, and schools are given the flexibility and authority to hire, assign, and fire teachers, and districts or systems are freed to reward effective schools and close low-performing schools, then teacher effectiveness will increase, along with student performance.

Also, Capacity Building Theory of Action presents an emphasis on the importance of instructional capacity building and the use of practice-centered criteria grounded in research on teaching and learning to define the characteristics of effective teaching. This research underscores the importance of pedagogical content knowledge; classroom management skills; understanding of students' social, cultural, and economic backgrounds; understanding of cognitive and human development; ability to collaborate with peers; and ability to cultivate partnerships with parents and the broader community as critical components of effective teaching.

The instructional capacity-building theory of action reasons that if schools and school districts provide supports that build the capacity of teachers to address the elements of effective teaching, then student performance will increase and achievement gaps will narrow (Wiske, 2008).

Consequently, the House's Path-Goal Theory from the Expectancy Theory argues that people act as they do because they expect their behavior to produce satisfactory results. In the path-goal relationship, the leader facilitates task accomplishment by minimizing obstructions to the goals and by rewarding followers for completing their tasks. The leader helps staff associate assess needs, explores alternatives, helps associates make the most beneficial decisions, rewards personnel for task achievement, and provides additional opportunities for satisfying goal achievement (Davis, 2007).

Moreover, the underlying philosophy work motivation coined by Vroom assumes that people want to satisfy some of their needs through hard work and they will do it if management will provide them with suitable environment. Among their desires are performing worthwhile tasks, sharing in group effort in setting their objectives, and sharing in the rewards on their efforts and continued personal growth (Falmagne, et al., 2010).

The demand for a quality education at present makes it very necessary and timely to determine the extent of utilization of the different approaches and strategies used by faculty handling basic PE course in state universities in Samar Island. The main concern of the faculty in teaching the subject is the performance of the learners. The poor performance of the students is an indication of the poor teaching performance of the instructors as to its approaches and strategies.

Assessment and evaluation is a science of providing information for purposes of making decisions. Performances

\section{Volume 6 Issue 12, December 2017}




\section{International Journal of Science and Research (IJSR) \\ ISSN (Online): 2319-7064}

Index Copernicus Value (2016): 79.57 | Impact Factor (2015): 6.391

that are not assessed and evaluated tend to maintain a status quo and to stagnate subsequently. Most likely, it produces constructive results and a necessary base for assessing present levels of attainment and planning subsequent improvements when viewed positively.

It is in this context that the researcher was prompted to draw the input-process-output model as paradigm of this study, serving as the study's conceptual framework in the determining the performance of faculty handling basic PE course in state universities in Samar Island. Through this, the strengths and weaknesses of the performance were discovered and the problems encountered during teaching were identified that needed to be addressed by higher education institutions towards the enhancement of their teaching. In fine, effective, and efficient delivery of services to the students were anchored through assessment and evaluation.

The input components consisted of the socio-demographic profile in terms of faculty factors (age, sex, civil status, highest educational attainment/degree earned, monthly salary, length of teaching physical education, seminars/trainings attended related to $\mathrm{PE}$ teaching, incentives and awards, class size, teaching strategies, and

attitude towards teaching), student factors (personal learning resources, grade point average in first semester, study habits, and school ability test), and the problems encountered in teaching the course and their needs.

The process was the sensitizing route, which paves the way to the assessment of the teaching performance rating based on the students' evaluation of the faculty performance, in terms of commitment, knowledge of subject matter, teaching for independent learning, management of student learning, course syllabus, methodology, performance, critic factor, instruction-teacher, instruction-students, instructionlearning environment, and other qualities.

Finally, it was conceptualized that the findings of this study provided insights/inputs needed in making a PE development plan to further increase or improve the quality and effectiveness of performance of faculty handling basic PE course in state universities in Samar Island.

The paradigm presented in Figure 1 shows the conceptualization of the study.

\section{Paradigm of the Study}

Process

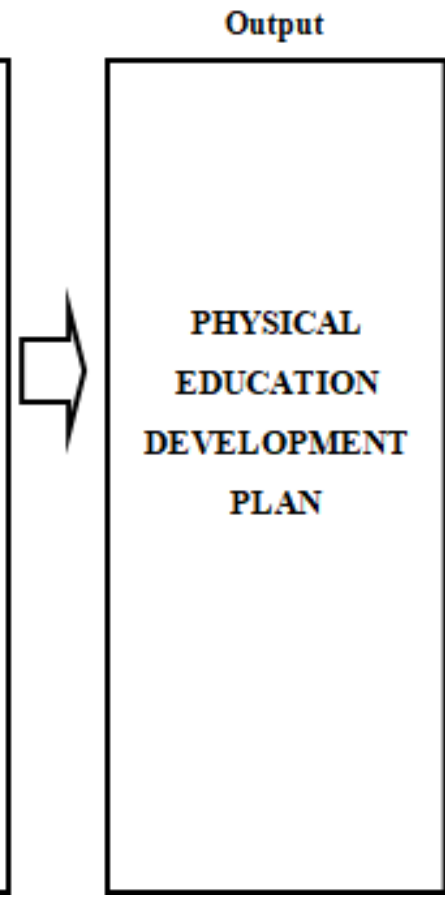

Figure 1: A schematic diagram showing the concept of the study

minimum requirements set by the aforementioned bodies and by local and foreign PE specialists (Miguel, 2013).

\section{Methodology}

This study was conducted in the state universities that are situated in Samar Island, namely Eastern Samar State University (Borongan City), Northwest Samar State University (Calbayog City), Samar State University (Catbalogan City), and University of Eastern Philippines (Catarman).
Geographically, the Samar Island occupies the eastern portion of the Philippines. It lies southeast of Luzon and occupies the northernmost section of Eastern Visayas. It is separated from Luzon on the north by San Bernardino Strait and from Leyte on the southeast by the narrow San Juanico Strait. It is bounded on the east by the Pacific Ocean, on the south by Leyte Gulf and on the west by the Samar Sea.

The province of Samar comprises the whole Samar Island before the approval of Republic Act 4221 on June 19, 1965 which divided the island into three provinces: Northern Samar, with Catarman as capital; Eastern Samar with

\section{Volume 6 Issue 12, December 2017}




\section{International Journal of Science and Research (IJSR) \\ ISSN (Online): 2319-7064}

Index Copernicus Value (2016): 79.57 | Impact Factor (2015): 6.391

Borongan City as capital; and Western Samar (officially known as Samar), with Catbalogan City as capital. Eastern Samar and Northern Samar bound the island of Samar on the east and north, respectively. Leyte Gulf on the south, and Samar Sea on the west.

The province of Samar is the largest among the three provinces that comprise the Samar Island, the third largest island in the country. Formerly called Western Samar, it is bounded on the north by Northern Samar, on the east by Eastern Samar, on the west by Samar Sea, and on the south by Leyte Gulf. It is composed of twenty-five (25) municipalities and two (2) cities, Calbayog and Catbalogan. It has two (2) congressional districts and has a total of 951 barangays.

Meanwhile, Northern Samar is located in the eastern part of the Philippine Archipelago bounded on the north by San Bernardino Strait, on the east by the Pacific Ocean, on the west by Samar Sea, and on the south by the province of Samar. it is composed of twenty four (24) municipalities and 569 barangays with two (2) congressional districts. It is strategically located as the gateway of Visayas and Mindanao from Luzon.

Eastern Samar has twenty-two (22) municipalities and the City of Borongan comprising one (1) congressional district. It is bounded on the east by the Philippine sea that form part the pacific Ocean; on the north by the province of Northern Samar; on the west by the province of Samar and on the south by the Leyte Gulf that merges further with Surigao Strait.

According to the 2009 Samar Island Profile, it has four (4) state universities situated in the island, namely: the University of Eastern Philippines (UEP) found in the capital town of Catarman, Northern Samar; the Samar State University (SSU) and Northwest Samar State University (NWSSU) found in the heart of the cities of Catbalogan and Calbayog respectively; and the Eastern Samar State University (ESSU) located in Barangay Maypangdan, Borongan City.

To assess and evaluate the performance of Physical Education faculty in state universities in Samar Island, the descriptive-correlational method was utilized in this study.

Descriptive designs provide comprehensive information about a problem or situation, its variables and its features. They are more precise in their focus and scope than exploratory designs. According to David (2005), a descriptive study uses more specific data gathering techniques, may involve various comparison groups in its attempt to produce a representative sample and provides specific and clear information regarding the problem. Descriptive research designs cannot control conditions nor test hypotheses.

This method was employed because it specifically aimed to identify the faculty's socio-demographic profile, the problems encountered in teaching Physical Education, and their needs.
This study also utilized the correlational design because it tried to test the hypotheses on relationship and difference. According to David (2005), this kind of method is used to describe the tendency for corresponding observations in two or more series to vary together from the averages of their respective series that is to have relative positions. This method of research creates a purposive process of gathering, analyzing, classifying, and tabulating data about prevailing conditions, practices, trends, and relationships to make adequate and accurate interpretation of data with the aid of statistical methods.

Using such design, this study tried to establish a relationship between the faculty's socio-demographic profile and their teaching performance, a relationship between the faculty's socio-demographic profile and the problems they encountered and their needs in teaching performance, and a difference between the assessment and evaluation of the four (4) state universities on the performance of faculty handling basic PE course.

The variables of this study composed of the input, process, and output variables.

\section{Input Variables}

Socio-Demographic Profile (Faculty Factors). The sociodemographic profile of faculty handling basic PE course in state universities in Samar Island included age, sex, civil status, highest educational attainment, length of teaching physical education, and seminars and trainings attended related to PE teaching, class size, attitude towards teaching, and teaching strategies.

Socio-Demographic Profile (Student Factors). The student factors included personal learning resources, grade point average in first semester, study habits, and school ability test.

Problems and Needs of Faculty. These were the problems and difficulties encountered by faculty handling basic PE course and their needs in teaching the PE subjects. The problems and needs were categorized into personal, students, instructional, and administrative factors.

\section{Process Variable}

Teaching Performance Rating. This pertains to the systematic judgment or evaluation of the students of state universities in Samar Island on the level of teaching performance of faculty handling basic PE course as reflected in the students' evaluation sheet on faculty members.

The teaching performance was measured into commitment, knowledge of subject matter, teaching for independent learning, management of student learning, course syllabus, methodology, performance, critic factor, instruction-teacher, instruction-students, instruction-learning environment, and other qualities.

Output Variable

Physical Education Development Plan.This was the output of this study to further increase or improve the quality, desirability, attractiveness or effectiveness of the 


\section{International Journal of Science and Research (IJSR) \\ ISSN (Online): 2319-7064 \\ Index Copernicus Value (2016): 79.57 | Impact Factor (2015): 6.391}

performance of faculty handling basic PE course and the PE instruction in state universities in Samar Island.

The population of this study was composed of regular, permanent, and special lecturer faculty handling the basic PE course in State Universities in Samar Island.

This study also included the students enrolled in the PE classes and the supervisors.

Complete enumeration was employed for the faculty and for the supervisors, while random sampling technique was used to determine the student-respondents.

The researcher asked a copy of the actual teaching loads of the faculty handling basic PE course for the second semester, school year 2015-2016 from the university's respective Office of the Registrar/Admission. From this list of 10,001 students, the respondents were selected through the fish-bowl technique. A total of 2,156 studentrespondents were determined by the researcher, using Slovin's formula (Broto, 2010).

The Respondents

This study involved the faculty handling basic PE course in state universities in Samar Island.

The state universities included in this study were Eastern Samar State University (Borongan City), Northwest Samar State University (Calbayog City), Samar State University (Catbalogan City), and University of Eastern Philippines (Catarman).

Moreover, the students enrolled in the PE classes during the second semester, school year 2015-2016 and the supervisors were also chosen as respondents of the study.

\section{Findings}

The findings of the study show that most of the facultyrespondents were 30 to 59 years old, female, married, had master's and doctorate's degree units and master's and doctor's degree holders, earned a monthly salary of P 35,000 and below, have been teaching for 1 to 15 years, attended 1 to 10 relevant seminars/trainings related to PE teaching, received 1 to 10 awards/incentives related to teaching PE, had a class size of 50 and below, had "highly favorable" teaching strategies, and had "favorable" attitude towards teaching. As to the student factors, most of the studentrespondents had access to books, cellphones, internet resources, dictionary, computers, encyclopedia, magazines, and journals as learning resources, most of them received an average grade of 1.50 during the first semester of school year 2015-2016, had "very satisfactory" study habits, and had a result of 51 to 75 in their aptitude test or school ability test.

As to the teaching performance, the students from ESSU, NWSSU, SSU, and UEP evaluated their faculty handling basic PE course "Very Satisfactory", in terms of commitment, knowledge of subject matter, teaching for independent learning, management of student learning, course syllabus, methodology, performance, critic factor, instruction - teacher, instruction - students, instruction learning environment, and other qualities.

Regarding the problems encountered by the faculty, the highest mean is on the item "Lack of sports/games facilities and equipment" and the lowest mean is on "Poor knowledge and skills in physical fitness, gymnastics, dance, and individual/dual/team sports and activities". Generally, the problems encountered were rated "moderately serious problems" in terms of instructional, personal, administrative, and student factors.

Concerning the needs of the faculty in their teaching performance, the faculty and the students rated "very much needed" and "much needed" respectively with the highest mean on "Adequate human and financial resources" and the lowest mean on "Have a double standard faculty in teaching PE subject". While the supervisors perceived the needs as "much needed" with the highest mean on "Have background knowledge and skills in physical fitness, gymnastics, dance, and individual/dual/team sports and activities" and "Exposure to various up-to-date methods and strategies in teaching the PE course" and the lowest mean on "Construction of buildings for safe teaching and learning process to suit specialized courses to the needs of the course". In general, the needs of the faculty members was rated "much needed" as to instructional, personal, administrative, and student factors.

On the test of relationship between the socio-demographic profile of the faculty and their teaching performance, regression analysis showed that all socio-demographic profile variables were found to be not significantly related to the teaching performance of faculty handling basic PE course.

The other test of relationship was conducted where the faculty's socio-demographic profile was hypothesized to have affected the problems they encountered and their needs in teaching performance. However, regression analysis revealed that among the 15 variables included; only study habits affected the problems encountered by the faculty. In addition, all the 15 variables were found to be not significantly correlated with the needs of the faculty in their teaching.

On the test of difference, there was no significant difference between the assessment and evaluation of the students in four (4) universities in Samar Island on the teaching performance of the faculty handling basic PE course.

Based on the findings of this study, a Physical Education Development Plan was formulated to further increase or improve the quality, desirability, attractiveness or effectiveness of the teaching performance of faculty handling basic PE course in State Universities in Samar Island.

\section{Conclusions and Implications}

In the light of the findings of the study, the following conclusions and implications were drawn:

\section{Volume 6 Issue 12, December 2017}




\section{International Journal of Science and Research (IJSR) \\ ISSN (Online): 2319-7064}

Index Copernicus Value (2016): 79.57 | Impact Factor (2015): 6.391

The faculty handling basic Physical Education course in the four universities of Samar Island possess enough personal and professional qualifications to be efficient and effective teachers of their respective university. This implies that they have that strong trust and courage needed to carry out responsibilities in the framework of morale and better teaching performance. As to the student factors, the students rely to different personal learning resources for their study and possess very satisfactory study habits as manifested in the results of their school ability test before entering tertiary education average grade in Physical Education course during the first semester of SY 2015-2016.

The teaching performance of the faculty is very satisfactory as evaluated by their respective students in terms of commitment, knowledge of subject matter, teaching for independent learning, management of student learning, course syllabus, methodology, performance, critic factor, instruction - teacher, instruction - students, instruction learning environment, and other qualities. This implies that they are highly efficient and effective in imparting knowledge and skills to the students on different Physical Education principles.

As to the problems encountered, the faculty, the students, and the supervisors perceived that the faculty moderately encountered problems in terms of instructional, personal, administrative, and student factors. This implies that there is a lack of sports/games facilities and equipment as perceived by the faculty. In addition, the students believed that the class size which is too crowded affects the teaching performance of the faculty. Likewise, the supervisors perceived that having extreme and diverse intellectual differences causes unsatisfactory performance.

Moreover, the faculty, the students and the supervisors perceived that the faculty are "much needed" in their teaching performance as to personal, student, instructional, and administrative factors. This means that to be efficient and effective in teaching the basic Physical Education course, the faculty are in need of adequate human and financial resources, specialists faculty in teaching the course, background knowledge and skills in physical fitness, gymnastics, dance, and individual/dual/team sports and activities, exposure to various up-to-date methods and strategies in teaching the course, and construction of buildings for safe teaching and learning process to suit specialized courses to the needs of the course.

The faculty factors and the student factors are not significantly correlated to the teaching performance of the faculty handling basic PE subject.

Likewise, the test of relationship on the faculty's sociodemographic profile and the problems they encountered and their needs in teaching performance is not significantly correlated with problems encountered and the needs of the faculty in their teaching except for the variable study habits which is significantly correlated. This implies that the faculty's profile and qualifications increase their teaching strategies and efficacy. In addition, study habits is significantly related, which indicates that good teaching performance results to a better study habits. As a results, it undoubtedly contributes to better performance not only in the PE course but in other academic assessments.

As to the test of difference, there is no significant difference between the assessment and evaluation of the students of the four universities in Samar Island on the teaching performance of the faculty handling basic PE course. This implies that students' evaluation on the faculty's teaching performance does not vary from what school they came from.

A Development Plan for PE Faculty is formulated to further increase or improve the teaching performance of the faculty handling basic PE course in state universities in Samar Island. The design will develop the quality, desirability, attractiveness, and effectiveness of the faculty performance when it comes to their commitment, knowledge of subject matter, teaching for independent learning, management of student learning, and course syllabus. Hence, the program will help create an environment that stimulates selected movement experiences resulting in desirable responses that contribute to the optimal development of the individual's capabilities in all phases of life.

\section{Theory Evolved}

As a result of an extensive and thorough analysis, the researcher came up with the theory "A Well-Managed and Accomplished Physical Education Program to a Better Teaching and Learning”.

This theory holds that a very satisfactory teaching performance results to better study habits, which greatly contributes to better performance not only in the Physical Education course but also in other academic endeavors or activities. Typically, the behavior is regarded as one of the causes of output, with output being one of the means by which the effectiveness of performance may be judged to faculty serving the institution. In other words, judgments are made about the effectiveness of faculty as they accomplish the results they achieve and the output they produce.

This theory further holds that to better achieve best teaching performance, study habits should be well emphasized by faculty being a true model and perfect sample in classroom learning and should be great motivators thus contributing efficient, effective, and developed teaching performance. Thus, main task of the students is to study properly and efficiently and they will be able to learn more. Their college life will be meaningful and challenging. Study habit is recognizing that the students are responsible for their successes and also their failures.

\section{Recommendations}

In the light of the findings and conclusions of the study, the following recommendations are hereby presented:

1) The faculty handling basic Physical Education course should pursue and finish post-graduate studies and attend relevant seminars/trainings related to PE teaching oftenly, present paper, publish research output, conduct extension services, and produce instructional materials

\section{Volume 6 Issue 12, December 2017}




\section{International Journal of Science and Research (IJSR) \\ ISSN (Online): 2319-7064}

Index Copernicus Value (2016): 79.57 | Impact Factor (2015): 6.391

for better qualifications of their job and for their enhancements of their teaching performance.

2) The faculty should be competent through exposure to various up-to-date methods and strategies by providing journals, latest books or references in teaching PE subjects which play a vital role in teaching performance and students' achievements.

3) Likewise, the university should subscribe monthly journals and collection of books related to PE thus creating a mini library.

4) Based on the evaluation of the teaching performance, it is hereby recommended that to further improve the faculty members' performance in teaching for independent learning, management for student learning, course syllabus, and methodology be given emphasis.

5) The university through its PE Department head or supervisor should properly schedule PE classes to minimize overcrowded class size. The Vice President for Academic Affairs should strictly monitor and supervise the number of students per class.

6) It is recommended that effective Physical Education specialists be hired particularly those who have background knowledge of PE principles and skills in physical fitness, gymnastics, dance, and individual/dual/team sports and activities.

7) The university should have a centralized PE department which could be a separate institution of human kinetics where all concerns and needs of faculty and students regarding $\mathrm{PE}$ be channeled to its department.

8) The university should attempt to improve the attitude of students to their academic work especially on PE course by providing sufficient and improve PE facilities for PE activities, learning materials, and equipments that are suited to the needs of the course.

9) That PE department should adopt latest programs relative to their subjects being taught as reflective in the faculty development plan created.

10) It is also recommended that the university consider the adoption of the proposed program on PE.

11) It is recommended that a follow-up study should be conducted with a wider scope and perspective in terms of respondents and objectives so that higher treatment of performance of faculty handling basic Physical Education course will be made and also explore and include other variables that might be significant and a research be conducted on study habits.

\section{References}

[1] _ B Bureau of Physical Education and School Sports.Department of Education.Retrieved from http://www.deped.gov.ph on November 10, 2015.

[2] _ Department of Education Handbook on Personnel.

[3] Abanes, F. R. 2007. The Performance of the Teachers of the De La Salle University-Dasmariñas.Unpublished Master's Thesis, De La Salle University-Dasmariñas, Cavite.Journal of Education. Volume 1, Number 1.

[4] Abasolo, P. A. 2005, Personal Management: The Efficiency Management of Employees. Unpublished Master's Thesis, Philippine Normal University, Manila.
[5] Ahmed, A. 2002.The Evaluation of the Physical Education Initial Teacher Training Program at Qatar University.Unpublished Ph.D. Dissertation. Durham University, Qatar.

[6] Aquino, G. V. 2009. Teaching Models, Strategies and Skills: A Guide to Efficient-Effective Teaching. Revised Edition. Manila, Philippines: Rex Book Store, Inc.

[7] Aquino, G. V., et al. 2008. Principles of Teaching Educational Technology.Revised Edition.Mandaluyong, Philippines: National Bookstore Company, Inc.

[8] Arends, R. 2011. Learning to Teach. New York, United States: McGraw-Hill Book Company, Inc.

[9] Armstrong, M. 2013. Employee Reward. London, United Kingdom: Chartered Institute of Personnel and Development House.

[10] Bahadır, Z. 2013. Performance Appraisal of Physical Education Teachers.Erciyes University, School of Physical Education and Sports, Kayseri, Turkey.Academic Journals on Education Research and Reviews. Volume 8, Number 7.

[11] Bailey, R. 2006. Physical Education and Sport in Schools: A Review of Benefits and Outcomes. Journal of School Health. Volume 76, Number 8.

[12] Bain, L. 2013. Physical Education Teacher Education.Handbook of Research on Teacher Education. New York, United States: Macmillan Publishing House.

[13] Beal, A. L. 2006.A Comparison of WISC-III and OLSAT-6 for the Identification of Gifted Students.Canadian Journal of School Psychology. Volume 11, Number 2.

[14] Beat, G. M., et al. 2002. Leadership and Dynamic. Iowa, United States: Iowa State University Press.

[15] Bertland, G. C. 2002. Rural Sociological Stratification in Rural Society.Revised Edition. New York, United States: McGraw-Hill Book Company, Inc.

[16] Bhalla, A. 2008. Attitude of Teachers Towards Teaching. Sevagram: Department of Medicine, MGIMS.

[17] Blue, T. W. 2001.The Teaching and Learning Process. District of Columbia, United States: National Education Association, Inc.

[18] Boiser, D. C. 2000. Strategies for Teaching: A Modular Approach. First Edition. Manila, Philippines: Rex Book Store, Inc.

[19] Bonsalagan, S. 2003. An Evaluation of the Implementation of the Secondary Education Program of Selected Secondary Schools in the Autonomous Region of Muslim Mindanao (ARMM).Unpublished Ph.D. Dissertation, Notre Dame University, Cotabato City.

[20] Brookhart, S. M. 2009. Grading.Pearson-Allyn-Bacon Prentice Hall, Pearson Education Inc.

[21] Broto, A. S. 2006. Statistics: Made Simple. Mandaluyong City, Philippines: National Book Store, Inc.

[22] Bullough, V. L and Bullough, B. C. 2002.Dressing Sex and Gender. Philadelphia, United States: University of Pennsylvania Press.

[23] Caine, R. N. and Caine, G. 2008.Education on the Edge of Possibility. Virginia, United States: 


\section{International Journal of Science and Research (IJSR) \\ ISSN (Online): 2319-7064}

Index Copernicus Value (2016): 79.57 | Impact Factor (2015): 6.391

Association for Supervision and Curriculum Development.

[24] Camacho, R. R. 2011. The Performance of the Elected Officials in Local Government Units in the First District of Northern Samar.Unpublished Master's Thesis, University of Eastern Philippines, University Town, Northern Samar.

[25] Campbell, J. 2001. Organization Behavior Foundations, Realities and Challenges. Quezon City, Philippines: Good Governance Books, Inc.

[26] Camposano, V. D. 2005. On-Campus Student Teaching in Teacher Training Institutions in Region VIII: Inputs to Teacher Education Program Development. Unpublished Ph.D. Dissertation, Philippine Normal University, Manila.

[27] Casale, M. A. 2011. Teachers' Perceptions of Professional Development: An Exploration of Delivery Models. Dissertation and Theses Collection.Retrieved from

http://scholarsarchive.jwu.edu/dissertations/AAI34504 17 on November 10, 2015.

[28] Casey, M. 2011. Perceived Efficacy and Preparedness of Beginning Teachers to Differentiate Instruction.Dissertation and Theses Collection.Retrieved from http://scholarsarchive.jwu.edu/dissertations/AAI34501 93 on November 10, 2015.

[29] Cetzels, J. W. 2008. Educational Administration as a Social Process: Theory Research and Practice. New York, United States: New Harper and Row Publishing House.

[30] Chase, Lirgg, and Sakelos. 2003. Teacher Efficacy and Effective Teaching Behaviors in Physical Education (Pedagogy). Research Quarterly for Exercise and Sport.

[31] Cole, P. et al. 2004. Teaching Principles and Practice.Second Edition. London, United Kingdom: Prentice Hall.

[32] Cortes, J. R. 2007. Education and National Development: The Philippine Experience and Future Possibilities. Revised Edition. Quezon City, Philippines: Publishers Printing Press.

[33] Covery, S. 2010. Seven Habits of Highly Effective People. New York, United States: The New York Times Company.

[34] Cui-Infante, A. 2001. Mathematics Competencies of Grade IV Teachers in Selected Schools in Northern Samar: Implication for Reform in Elementary Mathematics Education. Unpublished Dissertation, University of Eastern Philippines, University Town, Northern Samar.

[35] Darling-Hammond, L. 2000. Teacher Quality and Student Achievement: A Review of State Policy Evidence. Education Policy Analysis Archives. Volume 8, Number 1.

[36] Daum, D. N. 2012. Physical Education Teacher Educator's Attitudes Toward and Understanding of Online Physical Education.Unpublished Ph.D. Dissertation, University of Illinois at UrbanaChampaign, Illinois, United States.

[37] David, F. P. 2005. Understanding and Doing Research: A Handbook for Beginners. Iloilo City, Philippines: Panorama Printing, Inc.
[38] Davis, K. 2007. Human Behavior at Work.Fifth Edition. New York, United States: McGraw-Hill Book Company, Inc.

[39] De Vega, G. C. 2008. Educating the Mass for National Development.Philippine Journal Education.

[40] Dean, M., et al. 2005.The Effect of a Female Physical Educator's Appearance on Physical Fitness Knowledge and Attitudes of Junior High Students.Physical Educator. Volume 62, Number 1.

[41] Diaz, R. H. 1997. Communication and DecisionMaking Process of Teacher Education Institutions Among State Universities and Colleges in Region VIII. Unpublished Ph.D. Dissertation, University of Eastern Philippines, University Town, Northern Samar.

[42] DiBiase, D. 2014. Formative Assessment Professional Development: Impact on Teacher Practice. Dissertation and Theses Collection.Retrieved from http://scholarsarchive.jwu.edu/dissertations/AAI36219 76 on November 10, 2015.

[43] Dolan, S. L. 2010. Job Satisfaction and Life Satisfaction: Analysis of a Reciprocal. Retrieved from http://www.docstoc.com/docs/2380665 on November $10,2015$.

[44] Espedido, A. B. 2001. The School Administrators.The Modern Teacher. Volume 32, Number 7.

[45] Falmagne, J. P., et al. 2010. Victor Vroom's Work Motivation. The Assessment of Knowledge in Theory and in Practice. Retrieved from http://www.business.aleks.com/about/Science_Behind _ALEKS.pdf on November 10, 2015

[46] Florano, N. A. 2007. The Basic Education Curriculum (BEC) Implementation in the Secondary Schools in the Division of Northern Samar.Unpublished Master's Thesis, University of Eastern Philippines, University Town, Northern Samar.

[47] Florencio R. Abanes, 2007. The Performance Appraisal of the Teachers of the College of Education, De La Salle University-Dasmariñas.Unpublished Master's Thesis, De Las Salle University, Manila, Philippines.

[48] Foronda, M. A. 2002. Senate President Edgardo J. Angara and Republic Act No. 7432 - The Senior Citizens Act. Philippine Panorama. Volume 22, Number 40.

[49] Frase, L. E. and Sorenson, L. 2012. Teacher Motivation and Satisfaction: Impact on Participatory Management. NASSP Bulletin.

[50] Gavino, Z. 2013. The Teaching Performance in the Higher Institutions in Kalinga, Philippines: A Bench Mark for Quality Education. International Journal of Advanced Research in Management and Social Sciences. Volume 2, Number 10.

[51] Gorembalem, D. E. 2003. Some Variable Influencing Teaching Empowerment and Teaching Performance Among Secondary School Teachers in Northern Samar. Unpublished Master's Thesis, University of Eastern Philippines, University Town, Northern Samar.

[52] Graham, G., Holt-Hale, S. A., and Parker, M. 2008. Children Moving: A Reflective Approach to Teaching Physical Education. Fourth Edition. California, United States: Mayfield Publishing House. 


\section{International Journal of Science and Research (IJSR) \\ ISSN (Online): 2319-7064}

Index Copernicus Value (2016): 79.57 | Impact Factor (2015): 6.391

[53] Hardman, K. 2005. Global Vision of the Situation: Trends and Issues of Sport and Physical Education. Innovative Practices in Physical Education and Sports in Asia. Singapore City, Singapore: United Nations Educational, Scientific and Cultural Organization (UNESCO) Publication.

[54] Harrison, J. M., Blakemore, C. L., and Buck, M. M. 2011.Instructional Strategies for Secondary School Physical Education.Fifth Edition. Massachusetts, United States: McGraw-Hill Book Company, Inc.

[55] Houston, J. Responsible Officer: Head, Academic Skills and Learning Center. The Australian National University, Canberra.Retrieved from https://academicskills.anu.edu.au/resources/handouts/r esearch-skills-different-types-general-sources on February 14, 2016

[56] Humphries, C. and Ashy, M. 2006. 'The Confidence I Needed': Elementary Education Majors' Perceptions of Teaching Physical Education. Teacher Development. Volume 10, Number 2.

[57] Juico, P. E. 2012. Department of Sports and Sad State of Physical Education.Educational Setting in the Philippines.Mandaluyong, Philippines: National Book Store Company, Inc.

[58] Kelly, W. A. 2015. Educational Psychology.Revised Edition. Hawaii, United States: The Bruce Publishing Company.

[59] Kolf, D. 2002. The English Foreign Language Teacher as An Artist. English Teaching Forum.

[60] Kontz, H. 2003. Principle of Management: The Analysis of Managerial Functions. Revised Edition. New York, United States: McGraw-Hill Book Company, Inc. p. 397

[61] Krause, J. M. 2010. The Impact of Physical Education Student Teaching Experiences on Technology Integration Self-Efficacy. Unpublished Ph.D. Dissertation, University of Virginia, Virginia, United States.

[62] Kukla, A. 2003. Endogenous Constraints on Inductive Reasoning: Philosophical Psychology. The Research Journal.Volume 5.

[63] Labawig, M. C. 2008. Leadership Effectiveness of Barangay Captains: Its Implication to Barangay Development. Unpublished Master's Thesis, Saint Louis University, Baguio City.

[64] Lin, A. 2003. Problems Encountered by School Administrators in Selected Special Schools in Metro Manila. Unpublished Master's Thesis, Eulogio "Amang" Rodriguez Institute of Science and Technology, Manila.

[65] Llido, C. R. 2005. Communication and Human Relations Skills of Administrators in Different Schools and Colleges in Bohol.Unpublished Master's Thesis, Divine World College, Tagbilaran City, Bohol.

[66] Loffredo, V. J. 2001. The Influence of Different Delivery Systems on Cognitive Knowledge and Physical Wellness Measurements in a College Physical Education Class. Unpublished Ph.D. Dissertation, University of Houston, Texas, United States.

[67] Lupdag, A. D. 2004. Educational Psychology.Mandaluyong, Philippines: National Book Store Company, Inc.
[68] Maloney-Manley, J. A. 2015. Teachers' Self-Efficacy Regarding Standards-Based Reporting: A Needs Assessment for Professional Development. Dissertation and Theses Collection. Retrieved from http://scholarsarchive.jwu.edu/dissertations/AAI37012 46 on November 10, 2015

[69] Martin, J. 2006. Organizational Behavior and Management.Third Edition. New Jersey, United States: University of Hull Press.

[70] Martin, J., et al. 2009. The Impact of a Social Cognitive Theory-Based Intervention on Physical Education Teacher Self-Efficacy.Professional Development in Education. Volume 35, Number 4.

[71] Marzano, R. J., Pickering, D. J., and Pollock, J. E. 2001. Classroom Instruction that Works: ResearchBased Strategies for Increasing Student Achievement. Virginia, United States: Association for Supervision and Curriculum Development.

[72] Matchete, E. M. 2009. Classroom Leadership, Attitude Towards Teaching Science and Other Correlates of Teaching Competence of Science Teachers of Department of Education Science High Schools in the National Capital Region. Unpublished Dissertation, Polytechnic University of the Philippines, Manila.

[73] McCaughtry, N., et al. 2006. Teachers' Perspectives on the Challenges of Teaching Physical Education in Urban Schools: The Student Emotional Filter. Research Quarterly for Exercise and Sport. Volume 77, Number 4, pp. 486-497.

[74] Medina, B., Mendez, P., and Socano, L. 2014. The Filipino Family in Its Rural and Urban Orientation: Two Cases Studies and A Text with Selected Reading. Manila, Philippines: Centro Escolar University Research Development Press.

[75] Mendro, R. L. 2008. Student Achievement and School and Teacher Accountability.Journal of Personal Evaluation in Education.Volume 12.

[76] Miguel, C. T. 2013. Physical Education Program Competencies of Higher Education Institutions in Region 10: Enhancing Quality. The Mindanao Forum. Volume 26, Number 1.

[77] Miller, T. 2011. Educational Assessment.Academic Exchange Quarterly.Retrieved from http://www.rapidintellect.com on November 10, 2015.

[78] Mohr, D. J., Townsend, S. J., and Pritchard, T. 2006. Rethinking Middle School Physical Education: Combining Lifetime Leisure Activities and Sport Education to Encourage Physical Activity. Physical Educator, Volume 63, Number 1.

[79] Moreira, H., Fox, K. R., and Sparkes, A. 2002. Job Motivation Profiles of Physical Educators: Theoretical Background and Instrument Development. British Educational Research Journal. Volume 28, Number 6.

[80] Newstrom, J. W. and Davis, K. 2003. Organizational Behavior. Fifty-Ninth Edition. New York, United States: McGraw-Hill Book Company Inc.

[81] Peterson, K. D. 2005. Teacher Evaluation: A Comprehensive Guide to New Directions and Practices. California, United States: Corwin Press, Inc.

[82] Portman, P. A. 2003. Are Physical Education Classes Encouraging Students to be Physically Active? Experiences of Ninth Graders in Their Last Semester 


\section{International Journal of Science and Research (IJSR) \\ ISSN (Online): 2319-7064}

Index Copernicus Value (2016): 79.57 | Impact Factor (2015): 6.391

of Required Physical Education. Physical Educator, Volume 60, Number 3.

[83] Ramos, L. C. 2001. Quality Education: A Definition. The Modern Teacher. Volume 59, Number 10.

[84] Rebadulla, B. B. 2012. Correlates of Students' Performance in the National Achievement Test at the Laboratory High School, University of Eastern Philippines System.Unpublished Ph.D. Dissertation, University of Eastern Philippines, University Town, Northern Samar.

[85] Reich, L. M. 2012. Adapted Physical Education Teachers' Attitudes Towards Their Students with Hidden and Visible Disabilities. Unpublished Ed.D.Dissertation, California State University, California, United States.

[86] Reyes, E. C. 2004. Predictors of Professionalism and Teaching Performance of the Faculty Members of Selected State Universities and Colleges in CALABARZON. Unpublished Ph.D. Dissertation, Technological University of the Philippines.

[87] Robbins, S. P. 2001. Organizational Behavior.Ninth Edition. New Jersey, United States: Prentice Hall, Inc.

[88] Ryan, S., Fleming, D., and Maina, M. 2003. Attitudes of Middle School Students Toward Their Physical Education Teachers and Classes. Physical Educator. Volume 60, Number 2.

[89] Sagay, T. C. 2000.The Teacher as Role Model.The Modern Teacher. Volume 49, Number 7.

[90] Sanders, W. L. and Rivers, J. C. 2006.Cumulative and Residual Effects of Teachers on Future Student Academic Achievement. Tennessee, United States: University of Tennessee Value-Added Research and Assessment Center.

[91] Schmoker, M. 2009. Results: The Key to Continuous School Improvement. Virginia, United States: Association for Supervision and Curriculum Development.

[92] Shulman, I. S. 2012. Research on Teaching: A Historical and Personal Perspective. Effective and Responsible Teaching. California, United States: Jossey-Bass Publishing.

[93] Smith, J. M. 2008. The Evolution of Sex. Massachusetts, United States: Cambridge University Press.

[94] Smith, M. A. and St. Pierre, P. E. 2009. Secondary Students' Perceptions of Enjoyment in Physical Education: An American and English Perspective. Physical Educator. Volume 66, Number 4.

[95] Stevens-Smith, D. A., et al. 2006.Students' Perceptions of Academic Importance and Accountability in Physical Education.International Journal of Learning, Volume 13, Number 2.

[96] Stray, C. 2005. From Oral to Written Examinations: Cambridge, Oxford and Dublin 1700-1914. History of Universities. Volume 20

[97] Stronge, J. H. 2002. Qualities of Effective Teachers. Virginia, United States: Association for Supervision and Curriculum Development.

[98] Sullivan, E. 2015.Teachers' Perceptions of and SelfEfficacy in Modeling and Providing Opportunities for Social and Emotional Learning Competencies, Dissertation and Theses Collection. Retrieved from
http://scholarsarchive.jwu.edu/dissertations/AAI37009 97 on November 10, 2015

[99] Sullivan, E. C. 2007. Character Education in the Gymnasium: Teaching More Than the Physical. The Journal of Education.

[100]Tenedero, A. 2010.Theory and Practice of Public Administration in the Philippines.Revised Edition.Mandaluyong, Philippines: National Book Store Company, Inc.

[101]Terry, W. S. 2006. Learning and Memory: Basic Principles, Processes, and Procedures. Massachusetts, United States: Pearson Education, Inc.

[102] Waldman, D. A. 2004. The Contribution of Total Quality Management to a Theory of Work Performance.Academy of Management Review.Volume 19.

[103] Wanyama, M. N. and Quay, J. 2014. The Challenges of Teaching Physical Education: Juxtaposing the Experiences of Physical Education Teachers in Kenya and Victoria (Australia). African Journals Online for Physical, Health Education, Recreation, and Dance. Volume 20, Number 20. Retrieved from http://www.ajol.info/index.php/ajpherd/article/view/10 5595 on November 10, 2015.

[104]Welk, G. J. 2008. The Role of Physical Activity Assessments for School-Based Physical Activity Promotion.Measurement in Physical Education and Exercise Science. Volume 12, Number 3.

[105] White, B. 2002. Women's Career Development: A Study of High Flyers. Massachusetts, United States: Blackwell Publishing House, Inc.

[106]Wiersma, L. D. and Sherman, C. P. 2008.The Responsible Use of Youth Fitness Testing to Enhance Student Motivation, Enjoyment, and Performance.Measurement in Physical Education and Exercise Science, Volume 12.

[107] Wilson, E. K. 2001. Sociology: Rules, Roles, and Relationships. Illinois, United States: The Dorsey Press.

[108]Wiske, M. S. 2008. Teaching for Understanding: Linking Research with Practice. California, United States: Jossey-Bass Publishing.

[109]Woods, M. L., et al. 2008. Physical Educators' Technology Competencies and Usage.Physical Educator. Volume 65, Number 2.

[110]Wright, S. P., Horn, S. P., and Sanders, W. L. 2007. Teacher and Classroom Context Effects on Student Achievement: Implications for Teacher Evaluation. Journal of Personnel Evaluation in Education.Volume 11.

[111]Zemmelman, S., Daniels, H., and Hyde, A. 2013. Best Practice: New Standards for Teaching and Learning in America's Schools. New Hampshire, United States: Heinemann Publishing House.

[112]Zeng, H., et al. 2009. Physical Education in Urban High School Class Settings: Features and Correlations Between Teaching Behaviors and Learning Activities. Physical Educator, Volume 66, Number 4. 